AFRICAN AMERICAN RURAL EDUCATION 


\section{ADVANCES IN RACE AND ETHNICITY IN EDUCATION}

\section{Series Editors: Chance W. Lewis and James L. Moore III}

\section{Recent Volumes:}

Volume 1: $\quad$ Black Male Teachers: Diversifying the United States' Teacher Workforce. Edited by Chance W. Lewis and Ivory A. Toldson

Volume 2: African American Male Students in PreK-12 Schools: Informing Research, Policy, and Practice. Edited by James L. Moore III and Chance W. Lewis

Volume 3: Gifted Children of Color Around the World. Edited by Joy Lawson Davis and James L. Moore III

Volume 4: $\quad$ The School to Prison Pipeline: The Role of Culture and Discipline in School. Edited by Nathern S. Okilwa, Muhammad Khalifa and Felecia Briscoe

Volume 5: Advances in Race and Ethnicity in Education. Edited by James L. Moore III

Volume 6: Black Female Teachers: Diversifying the United States' Teacher Workforce. Edited by Abiola Farinde-Wu, Ayana Allen-Handy, Chance W. Lewis 
ADVANCES IN RACE AND ETHNICITY IN EDUCATION VOLUME 7

\section{AFRICAN AMERICAN RURAL EDUCATION: COLLEGE TRANSITIONS AND POSTSECONDARY EXPERIENCES}

\section{EDITED BY \\ CRYSTAL R. CHAMBERS \\ East Carolina University, USA \\ AND \\ LONI CRUMB \\ East Carolina University, USA

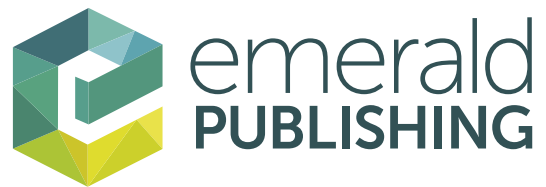

United Kingdom - North America - Japan India - Malaysia - China 
Emerald Publishing Limited

Howard House, Wagon Lane, Bingley BD16 1WA, UK

First edition 2021

(C) 2021 Emerald Publishing Limited.

Reprints and permissions service

Contact: permissions@emeraldinsight.com

No part of this book may be reproduced, stored in a retrieval system, transmitted in any form or by any means electronic, mechanical, photocopying, recording or otherwise without either the prior written permission of the publisher or a licence permitting restricted copying issued in the UK by The Copyright Licensing Agency and in the USA by The Copyright Clearance Center. Any opinions expressed in the chapters are those of the authors. Whilst Emerald makes every effort to ensure the quality and accuracy of its content, Emerald makes no representation implied or otherwise, as to the chapters' suitability and application and disclaims any warranties, express or implied, to their use.

\section{British Library Cataloguing in Publication Data}

A catalogue record for this book is available from the British Library

ISBN: 978-1-83909-871-0 (Print)

ISBN: 978-1-83909-870-3 (Online)

ISBN: 978-1-83909-872-7 (Epub)

ISSN: 2051-2317 (Series)

\section{ISOQAR certified}

Management System,

awarded to Emerald

for adherence to

Environmental

standard

ISOQAR

ISO 14001:2004. 


\section{CONTENTS}

List of Tables and Figures vii

List of Contributors ix

Foreword $x i$

Preface xiii

African American Rural Students: Exploring the Intersection of Place and Race

Elise J. Cain

\section{SECONDARY EDUCATION PATHWAYS}

Passport with No Access: The Habitus and Cultural Capital Influences of Rural, African American, and Low Socioeconomic Status Students' College Aspirations

Cara M. Gafford

Black, Gifted, and Living in the "Country": Searching for Equity and Excellence in Rural Gifted Education Programs

Joy Lawson Davis, Donna Y. Ford, James L. Moore III and

Erinn Fears Floyd

Black Males in Rural Contexts: Challenges and Opportunities

Erik M. Hines, James L. Moore III, Renae D. Mayes,

Paul C. Harris, Paul Singleton II, Christian M. Hines,

Chris J. Harried and Bobbi-Jo Wathen

\#BlackGirlMagic: The (Mis)education of Gifted Black Girls

from Economically Disadvantaged, Rural Communities

Raven K. Cokley and Loni Crumb 


\section{POSTSECONDARY EDUCATION PATHWAYS \\ AND EXPERIENCES}

The Privileged Rural: The College Experiences of Rural African Americans

J.H. Flowers

Rural Pathways to Higher Education: The Role of Mathematics Achievement and Self-efficacy for Black Students

Crystal R. Chambers

Rural, Black, and Distant: Building Relationships to Foster Higher Education Access

Jason Combs, Michelle L. Boettcher, Amber Lange and Sara Hanks

The Culturally Relevant Classroom Management Competence of Novice Teachers

Tremaine R. Young and Crystal R. Chambers

Advancing Rural Administrators and Teacher Leaders:

Educational Opportunity in the Alabama Black Belt

Tricia J. Stewart and Nicole DeRonck

Outsiders Within: Critical Perspectives of Black/African American Women Teaching Multicultural Counseling in Rural Appalachia

Adrienne N. Erby and Dominique S. Hammonds

Afterword

Kassie Freeman

About the Series Editors

About the Authors 


\section{LIST OF TABLES AND FIGURES}

Table 1. Gender and Grade Level of the Sample Group $(\mathrm{n}=82) . \quad 28$

Table 2. College Aspirations Percentages by Gender $(\mathrm{n}=82) . \quad 28$

Table 3. Background Characteristics Frequency Table $(n=82) . \quad 28$

Table 4. Students' Length of Time in SECHS District. 29

Table 5. Access to College Resources Percentage $(\mathrm{n}=82)$. 29

Table 6. College Aspirations Correlations $(\mathrm{n}=82) . \quad 30$

Table 7. Linear Regression Coefficients $(\mathrm{n}=82) . \quad 30$

Table 8. Regression Precollege Resources. 31

Table 9. Correlations by Gender $(\mathrm{n}=82) . \quad 32$

Table 10. Regression by Gender $(\mathrm{n}=82) . \quad 32$

Table 1. Geographic Definition of Rural. 108

Table 2. $\quad$ Rural Black Students' Highest Degree Aspirations (\%). 110

Table 3. Postsecondary Enrollment/Persistence of Black Rural Students by Program/Institutional Type (\%). 110

Table 4. Mathematics Achievement and Self-Efficacy of Black Rural Students (\%). 111

Table 5. Black Rural Student 2012 Mathematics Performance and Self-efficacy by Postsecondary Enrollment in 2016. 112

$\begin{array}{lll}\text { Table 1. Participants. } & 139\end{array}$

Figure 1. A Comparison of the Educational Attainment of all Rural People Compared to White Rural People and African American Rural People, 2015.

Figure 1. Challenges Faced by Black Gifted Students in Urban and Rural Settings. 43

Figure 1. Emerging Scholars Retention Rate by Cohort. 127 
This page intentionally left blank 


\section{LIST OF CONTRIBUTORS}

Michelle L. Boettcher

Elise J. Cain

Crystal R. Chambers

Raven K. Cokley

Jason Combs

Loni Crumb

Joy Lawson Davis

Nicole DeRonck

Adrienne Erby

Jamon Flowers

Erinn Fears Floyd

Donna Y. Ford

Kassie Freeman

Cara M. Gafford

Dominque S. Hammonds

Sara Hanks

Paul C. Harris

Grant B. Hayes,

Christian M. Hines

Erik M. Hines

Chris J. Harried

Amber Lange

Renae D. Mayes

James L. Moore III

Paul Singleton II

Tricia J. Stewart

Tremaine R. Young
Clemson University

Georgia Southern University

East Carolina University

University of Georgia

Clemson University

East Carolina University

Independent Scholar - Equity in Gifted Education

Western Connecticut State University

Ohio University

University of Georgia

National Association for Gifted Children

The Ohio State University

African Diaspora Consortium

Bowie State University

Appalachian State University

Clemson University

University of Virginia

East Carolina University

The Ohio State University

Florida State University

Ball State University

Clemson University

Ball State University

The Ohio State University

University of Connecticut

Western Connecticut State University

East Carolina University 
This page intentionally left blank 


\section{FOREWORD}

Our lives, perspectives, hopes, and dreams are influenced by our race which is not the true determinant of our future or what we were put here to be or do. Race is a social construct and its meaning in the lives of individuals varies. Although there is a definition of race, there is not one universal practical way that one lives or defines his or her individual way of being in a race that would make a lived experience monolithic, only one's outer shell and assumptions about life in that shell which is not the individuals' reality in its purest form.

Perhaps, race for true southern African American males, like ourselves, who are academic leaders and employ a personal philosophy of embracing the wisdom of elders, males, and females, about masculinity, race, and culture, and the importance of being authentic challenges the assumptions and stereotypes about the African Americans from the rural South.

From our interpretation and commonality, growing up in the rural South, the context of family was extremely influential on our development and expectations of responsibility to self, family, community, and world. The ability to interact with multiple generations of family members gave us a sense of identity and belonging that was extremely important for the developmental years. Just sitting at the feet of our elders conveyed a family structure that honored and simply respected them and trusted what they said to be of value. Looking at their hands and their faces penetrated our consciousness of the fact that their ordinary existence was proof enough to honor their extraordinary lives and spirits.

We are reminded who we are each day and of our elders' love for us by the fact that they took the time to not only be with us but to involve us in the daily simple tasks of life so that we could bring our unique self into being. From getting water out of the country well; to picking and shelling beans from the garden; to helping gather wood for the stove; to making biscuits for dinner. What is extra special about one's experiences is the notion that we were never judged for being ourselves or thinking out of the box to solve simple problems.

The stillness of sitting on the porch in the summer in anticipation of a storm by smelling the rain in the air before it arrived. Experiences, like this one, certainly taught us patience, self-control, reflections, appreciation, and the art of stillness and imagination. The lessons with our elders in the rural South also gave us lessons in character which bleeds into the way we communicate with others.

Because we were born and raised in the 1960s and came of age in the 1970s and 1980s, we experienced some of the most transitional and powerful discoveries in history that affects how we are in the world. We have always lived in an integrated world, regardless of what others might think about the south, life was good and kind. We experienced classrooms with both Black and White teachers 
and Black and White classmates whose social economic status was similar to our own. We watched men go off to work, pray in church, and take part in building our communities. We watched mothers who stayed home and others who went off to work in textile mills, hospitals as nurses, or the field for seasonal work. Regardless, there was the expectation that your community had for you to get an education and be the best you that you can be for yourself and community. Make a difference in the world; put God first; do unto others as you would have them do unto you; and know that you were loved were messages that sustain us through our adolescence and young adulthood.

As academic leaders, many times the only Black person in the room, who shoulders the responsibility to education and enlighten our peers about behavior, policies, and assumptions regarding those who were not like them. This is an issue of respect and honoring all while teaching them that the whole is as important as the parts. We must take a broad lens when dealing with discrimination in our current time. We must take the humanistic approach which is not a complicated one and remember to continue to penetrate the consciousness of all

We are so pleased to be asked to write the foreword for this exceptional work. The authors should be commended for exploring these important and challenging topics related to African American rural education. Black rurality is generally underexplored. This work contributes greatly to scholarship as it reflects the experiences, challenges, and triumphs of Black rural people just like us.

B. Grant Hayes, PhD, Acting Provost and Senior Vice Chancellor, East Carolina University

Lemuel Watson, $\mathrm{PhD}$, Dean and Professor, School of Education, Indiana University 


\section{PREFACE}

We are excited to share Volume 7 - African American Rural Education: Postsecondary Pathways and Experiences in the Advances in Race and Ethnicity in Education book series. Volume 7 brings novel perspectives on the secondary and post-secondary educational experiences of African American students, administrators, and educators living in rural communities. Current literature on rural education is White dominated. Sparse attention is given towards an understanding of the educational challenges and collegiate trajectories of rural African Americans. Yet, nearly 20 percent $(19.3 \%)$ of the US population is rural and African Americans comprise the largest racial/ethnic minority group in rural settings, about 2.6 million people. Moreover, with reverse migration from urban centers, there are increasing numbers of African Americans returning to rural communities as well as communities concentrated in the American (US) South that remain predominantly Black over time (DeShay, 2020; Housing Assistance Council, 2012; Schaeffer, 2019). The majority of Blacks in the US are not poor, but many particularly in areas in the American (US) South have endured persistent, intergenerational poverty (USDA, 2018). While literature on rurality addresses poverty, it does not address experiences from a Black perspective, excluding experiences of Black culture as well as structural and interpersonal racism. In the words of contributing author, Tremaine Young, "it's one thing to be poor and rural. It is another thing to be Black" (2019). This observation was made after Dr. Young hired a White teacher from coal mining country to work at a school in a majority Black rural school district and he observed a cultural mismatch.

Thus, specific attention to African American students in rural settings is warranted. The purpose of the volume is to attend to the challenges, trajectories, and opportunities of African American rural students as they move from secondary to postsecondary education. The volume consists of an introduction and 10 chapters from contributing scholars across multiple disciplines who provide research findings and theoretical ideology related to rurality and education. Through this volume, it is our hope that educators, policy makers, and social media influencers will garner a better sense of what it means to be African American in a rural environment as well as develop culturally informed pedagogies/andragogys that will assist in supporting the educational trajectories of rural African American students.

This volume opens with a foreword by Grant Hayes, Acting Provost and Senior Vice Chancellor of Academic Affairs at East Carolina University and Lemuel Watson, Dean and Professor in the School of Education at Indiana University, who set the tone for the volume by sharing their appreciation for rural 
living and African American cultural values that have an ongoing influence in their current positions in university leadership. The Foreword is followed by an introduction by Elise J. Cain titled African American Rural Students: Exploring the Intersection of Place and Race. Cain sets the context for the rest of this collection with an exploration of the intersection of race and geographic location for African American students. She brings together the contemporary push to increase college enrollments among rural students in an effort to mitigate population declines among traditional college students nationwide with an understanding of rurality formally defined and socially constructed as intersected with race. Higher education institutions are now recognizing rural communities as valuable places for new college recruiting initiatives; however, given the suboptimal primary and secondary educational experiences of African American rural students, there is a need to prime the postsecondary educational pump so that these students receive the educational content, knowledge of college, and support needed to be successful.

The rest of the volume is divided into two sections, focusing on secondary and post-secondary education settings. This first section lays the groundwork for postsecondary pathways through the examination of the secondary level education experiences of African American rural students. In Chapter 1, Passport with No Access: The Habitus and Cultural Capital Influences of Rural, African American and Low Socioeconomic Status Students' College Aspirations, Cara M. Gafford finds that rural African American students' college aspirations are associated with their academic self-concept; but that students' aspirations exceeded their "circle of influence" or social capital. As such, she challenges institutions to seek earlier opportunities to interject college and career conversations in order to cultivate African American students' college aspirations. In Chapter 2, Black, Gifted, and Living in the 'Country': Searching for Equity and Excellence in Rural Gifted Education Programs, Joy Lawson Davis, Donna Y. Ford, James L. Moore, III, and Erinn Fears Floyd extend the constraints of race and place in the identification of brilliance among African American rural students. Focusing on within race gendered experiences, Authors Erik M. Hines, James L. Moore, III, Renae D. Mayes, Paul C. Harris, Paul Singleton, II, Christian M. Hines, and Chris J. Harried discuss the interconnections of rurality and Black male identity in Chapter 3, Black Males in Rural Contexts: Challenges and Opportunities. In the following chapter, \#BlackGirlMagic: The (Mis)education of Gifted Black Girls from Economically Disadvantaged, Rural Communities, Raven K. Cokley and Loni Crumb discuss the intersections of intellectual ability, race, gender, social class, and place, calling attention to the underrepresentation of girls from rural, economically disadvantaged backgrounds in gifted education programs from a Critical Race Feminist Perspective.

In the second section, focused on postsecondary pathways and experiences, authors consider student trajectories, experiences, and institutional responses to the needs of African American rural college students. The section opens with Chapter 5, The Privileged Rural: The College Experiences of Rural African Americans. Jamon Flowers uses W.E.B. Du Bois' double consciousness framework to explore how African American rural students experience college. 
In Chapter 6, Rural Pathways to Higher Education: The Role of Mathematics Achievement and Self-Efficacy for Black Students, Crystal R. Chambers discusses differences in the trajectories of Black rural students, whether attending a two or four-year institution as compared to no college enrollment. The difference among students all comes down to mathematics as students with higher scores tend to attend four-year institutions, whereas those who attend two-year institutions or have no collegiate experiences are not statistically distinct. The implication is that in order to improve Black rural students' college access, we must address the quality and quantity of mathematics education in the secondary school context. In the next chapter, Rural, Black, and Distant: Building Relationships to Foster Higher Education Access relays a creative approach to engaging Black rural students through the Emerging Scholars Program at Clemson University. Jason Combs, Michelle L. Boettcher, Amber Lange, and Sara Hanks present the Emerging Scholars Program as a model for programming connecting universities to rural communities, cultivating postsecondary access and outcomes for African American rural students. In Chapter 8, The Culturally Relevant Classroom Management Competence (CRCM) of Novice Teachers, Tremaine Young and Crystal R. Chambers explore the relative influence of teacher preparation on the culturally relevant classroom management competence of novice teachers. They find that multiple decades of immersion within one's own community is not interrupted by a few years in a teacher education program, whether at an HBCU or PWI. Greater intentionality within teacher preparation programs, postgraduation continued induction and professional development is necessary to cultivate CRCM competency among novice teachers. Tricia J. Stewart and Nicole DeRonck add to the conversation of educator preparation in Chapter 9, Advancing Rural Administrators and Teacher Leaders: Educational Opportunity in the Alabama Black Belt. They examine the influence of a doctoral program in educational leadership in cultivating educational opportunities for K-12 African American rural students. Finally, African American professors Adrienne Erby and Dominique S. Hammond examine the influences of their positionality on their pedagogy, curricular content and approach, experiences with students, and institutional climate in the final chapter, Outsiders Within: Critical Perspectives of Black/African American Women Teaching Multicultural Counseling in Rural Appalachia. We close the volume with a reflective Afterword by Kassie Freeman, President and CEO of the African Diaspora and Senior Faculty Fellow Institute for Urban and Minority Education at Teachers College, Columbia University.

The authors of this volume hail from a variety of disciplines as the postsecondary trajectories of African American rural students are stymied by various influences such as social, economic, psychological, and political forces which may damper the ability of these students to seamlessly progress from secondary to postsecondary education. Just as the context of African American rural students is complex, there is also a need for multifaceted solutions to disentangle the effects of race and place to secure affirming educational pathways for rural African American students. We are grateful for the knowledge of each contributor and the voice they give to African American rural education in this volume. 


\section{References}

DeShay, A. (2020). African American population data, 2d. Retrieved from Blackdemographics.com Housing Assistance Council. (2012). Race and ethnicity in rural America: Rural research brief. Retrieved from http://www.ruralhome.org/storage/research_notes/rrn-race-and-ethnicity-web.pdf

Schaeffer, K. (2019, November 20). In a rising number of US counties, Hispanic and black Americans are the majority. Pew Research Center. Retrieved from https://www.pewresearch.org/fact-tank/ 2019/11/20/in-a-rising-number-of-u-s-counties-hispanic-and-black-americans-are-the-majority/

US Department of Agriculture (USDA). (2018). Rural America at a glance. Economic Information Bulletin 200. Economic Research Service, US Department of Agriculture. Retrieved from https://www.ers.usda.gov/webdocs/publications/90556/eib-200.pdf

Young, T. (24, June 2019). Novice teachers' preparedness towards successfully interacting with culturally diverse student populations. A dissertation proposal defense to the Graduate Faculty of East Carolina University. 